\title{
Vigor tests for evaluation of crambe (Crambe abyssinica Hochst) seed quality ${ }^{1}$
}

\author{
Sara Michelly Cruz ${ }^{2 *}$, Marcela Carlota $\mathrm{Nery}^{2}$, Adriana de Souza Rocha ${ }^{2}$, \\ Édila Vilela de Resende Von Pinho ${ }^{3}$, Paulo César de Resende Andrade ${ }^{4}$, \\ Denise Cunha Fernandes dos Santos Dias ${ }^{5}$
}

\begin{abstract}
The aim of this study was adapting the methodology of the accelerated aging test (AA) and electrical conductivity test (EC) to evaluate seed quality of crambe, as well as verifying enzymatic activity in relation to vigor differences. Crambe seed lots, cv. FMS Brilhante, were evaluated by the AA test, for periods of $0,24,48,72$ and $96 \mathrm{~h}$, at $42{ }^{\circ} \mathrm{C}$, with and without $\mathrm{NaCl}$ saturated solution; and the EC test, by soaking seeds into deionized water $(\mathrm{mL})$ in the ratios of $25 / 25,25 / 50,50 / 50$ and 50/75 (seed/water) for 2, 4, 6, 8, 10, 12, 14, 16 and $18 \mathrm{~h}$. The electrophoretic profile for isozymes esterase, superoxide dismutase, catalase, isocitrate lyase, alcohol dehydrogenase and malate dehydrogenase was evaluated on polyacrylamide gel (7.5\%). The AA test conducted at $42^{\circ} \mathrm{C}$, for $96 \mathrm{~h}$, was efficient to detect differences on seed quality levels; however, the EC test was not suitable to evaluate vigor of those seeds. The bands stained for isozymes esterase, superoxide dismutase and catalase were evident for the more vigorous seeds; and the bands for isozymes isocitrate lyase and alcohol dehydrogenase were less evident for the less vigorous seeds. For enzyme malate dehydrogenase enzyme intensity of bands was similar.
\end{abstract}

Index terms: accelerated aging, electrical conductivity, enzymatic profile.

\section{Testes de vigor para a avaliação da qualidade de sementes de crambe (Crambe abyssinica Hochst)}

\begin{abstract}
RESUMO - O objetivo deste estudo foi adequar a metodologia dos testes de envelhecimento acelerado (EA) e condutividade elétrica (CE) para avaliar a qualidade de sementes de crambe, bem como verificar a atividade enzimática nessa semente em relação às diferenças de vigor. Para isso sementes de crambe (cv FMS Brilhante) foram submetidas ao teste EA, durante 0, 24, 48, 72 e 96 h, a $42{ }^{\circ} \mathrm{C}$, com e sem solução saturada de $\mathrm{NaCl}$; e ao teste $\mathrm{CE}$, com imersão das sementes em água deionizada, nas proporções de 25/25, 25/50, 50/50 e 50/75 (semente/água), durante 2, 4, 6, 8, 10, 12, 14, 16 e $18 \mathrm{~h}$. O perfil eletroforético para esterase, superóxido dismutase, catalase, isocitrato liase, álcool desidrogenase e malato desidrogenase foi avaliado em gel de poliacrilamida (7,5\%). O teste EA conduzido a $42^{\circ} \mathrm{C}$, durante $96 \mathrm{~h}$, foi eficiente para detectar diferenças nos níveis de qualidade; porém, o teste CE não foi adequado para avaliar o vigor dessas sementes. As bandas coradas para esterase, superóxido dismutase e catalase foram mais nítidas para sementes menos vigorosas; e as bandas para isocitrato liase e álcool desidrogenase foram menos nítidas para sementes menos vigorosas. Para a enzima malato desidrogenase a intensidade das bandas foi semelhante.
\end{abstract}

Termos para indexação: envelhecimento acelerado, condutividade elétrica, perfil enzimático.

\section{Introduction}

Originally from Ethiopia, the herbaceous plant crambe (Crambe abyssinica Hochst) is an oilseed plant of short cycle and annual cultivation belonging to the genus Brassica spp. (Lazzeri et al., 1995). In Brazil, only the cv. "FMS Brilhante",

${ }^{1}$ Submitted on $04 / 12 / 2013$. Accepted for publication on 07/11/2013. ${ }^{2}$ Departamento de Agronomia, Universidade Federal dos Vales do Jequitinhonha e Mucuri, 39100-000 - Diamantina, MG, Brasil.

${ }^{3}$ Departamento de Agricultura, Universidade Federal de Lavras, Caixa Postal 3037, 37200-000 - Lavras, MG, Brasil. which was registered in 2007, is used in extensive cultivations. Even though, for its potential to produce biodiesel, the crop is becoming important nationwide because of the easiness of its cultivation and the quality of oil produced, besides the wide range of byproducts extractable from its oil (Pitol et al., 2010).

However, for efficient productive systems are successfully

\footnotetext{
${ }^{4}$ Instituto de Ciência e Tecnologia, Universidade Federal dos Vales do Jequitinhonha e Mucuri, 39100-000 - Diamantina, MG, Brasil.

${ }_{5}^{5}$ Departamento de Fitotecnia, Universidade Federal de Viçosa, 36570-000 -

Viçosa, MG, Brasil.

*Corresponding author <saramicz@yahoo.com.br>
} 
established for this crop in the country, the use of high quality seeds is essential; as they will allow the traits for high productivity, or others desirable traits, developed by genetic breeding programs for the cv. FMS Brilhante are transferred to farmers. Among the vigor tests available and recommended towards this end, there is still no specific method to assess the physiological quality of crambe seeds.

Among the vigor tests available, the tests of electrical conductivity and accelerated aging are very efficient in terms of standardization, since besides providing reproducible results are directly correlated to emergence of seedlings in the field, physiological potential of seeds, and to storage conditions; besides low cost, easiness, and execution speed (Hampton and TeKrony, 1995).

The ideal conditions for carrying out the accelerated aging test may vary with the plant species assessed, the temperature at which the test is performed, the seed incubation period, and the type of solution used to maintain the relative humidity $(\mathrm{RH})$ within the incubation chamber. On assessing small seeds, excessive RH may cause seed deterioration thus allowing fungal developments, both pathogenic as storage fungi, which may impair results. According to Jianhua and McDonald (1997), one of the alternatives for reducing the RH contained within the incubation chamber is the use of concentrated $\mathrm{NaCl}$ solution, which retains part of the RH. The standard accelerated aging method in which the seeds are subjected to the temperature of $42{ }^{\circ} \mathrm{C}$, and $100 \% \mathrm{RH}$, for 48,72 , or $96 \mathrm{~h}$, are recommended for seeds of cabbage (Brassica oleracea var. capitata L.) and seeds of broccoli [Brassica oleracea (L.) var. italica Plenk] (Costa et al., 2008); and at temperature of $42{ }^{\circ} \mathrm{C}$, and $100 \%$ UR, for $24 \mathrm{~h}$, are recommended for seeds of canola (Brassica napus (L.) var. oleifera Del.) (Avila et al. 2005). However, the alternative method using concentrated $\mathrm{NaCl}$ solution, and performed at $42{ }^{\circ} \mathrm{C}, 76 \%$ $\mathrm{RH}$, for $48 \mathrm{~h}$, is likewise recommended to assess the broccoli seeds (Martins et al., 2002; Tunes et al., 2012).

As for the EC test, the methodologies developed so far to each plant species have been adequate. However, depending on the species assessed the volume of deionized water used in the soaking process varies from 25,50 or $75 \mathrm{~mL}$, for soaking samples with 25 or 50 seeds during different periods (Kikuti and Marcos-Filho, 2008; Souza et al., 2009; Milani et al., 2012). Nevertheless, once the test allows obtaining results in lesser time (between 4 and $18 \mathrm{~h}$ ), the $24 \mathrm{~h}$ soaking period is the most used to evaluated the seeds of some specific crops (Kikuti and Marcos-Filho, 2008; Milani et al., 2012).

Currently, several studies involving techniques of isozyme electrophoretic analyses have been carried out aiming at better understanding what occurs during the seed deteriorative process. These analyzes allow detecting the biochemical changes linked to seed deteriorative process by determining the activity of the enzymes associated to the degradation of cell membranes, as well as to the respiration processes, germination, and metabolism of the seed nutritional reserves (Ventura et al., 2012).

In face of the foregoing, this study was aimed at determining a specific methodology of the AA and EC tests to evaluate physiological quality of crambe seeds; as well as to investigate the changes in the enzymatic activity occurring in these seeds in relation to their vigor differences.

\section{Material and Methods}

The experiments were carried out in the Seed Testing Laboratory, Universidade Federal dos Vales do Jequitinhonha e Mucuri (UFVJM), municipality of Diamantina, MG, and in the Central Seed Testing Laboratory, Universidade Federal de Lavras, Lavras, MG, Brazil. The crambe seeds, cv. FMS Brilhante, used for carrying out the experiments were originated from five different lots, which were provided by the State of South Mato Grosso Foundation. Seeds of lots 1 and 2 were harvested in the 2011 crop season; seeds of lot 3 were harvested in the 2009 crop season; the seeds of lot 4, in the 2010 crop season; and the seeds from the lot 5 were harvested in the 2008 crop season.

Seed moisture content (MC) was determined by the oven method, at $105^{\circ} \mathrm{C}$, for $24 \mathrm{~h}$ (Brasil, 2009), with two replications of $4.5 \mathrm{~g}$ seeds each, and results expressed in percentage.The tests for assessing percentage seed germination (PG) and seedling emergence (SE) was carried out with four replicates of 50 seeds each. To that, the seeds from each replication were sown in plastic trays containing a substrate composed by the mixture of soil + sand (1:2); and the substrate moisture was adjusted to $60 \%$ of water holding capacity. Immediately after, these trays were placed into a germination chamber, set to $25^{\circ} \mathrm{C}$, and photoperiod of $12 / 12 \mathrm{~h}(\mathrm{~L} / \mathrm{D})$; and the evaluations were daily performed. The first count of germination (FCG) was performed on the fourth day after sowing (DAS), and the final germination counting (FGC) was carried out on the seventh DAS. The counting of number of normal seedlings emerged was performed until the stand stabilization, what occurred on the tenth DAS. Results were expressed as percentage of normal seedlings emerged (Brasil, 2009).

The germination speed index (GSI) and the seedling emergence speed index (ESI) were computed using the equation proposed by Maguire (1962).

Seed health test (HT) was carried out by the use two different methods: the blotter test method, with the substrate moistened with 2,4-D (5 ppm), and the freezing method, 
performed at $-20{ }^{\circ} \mathrm{C}$, for $24 \mathrm{~h}$; which were used to delay the speed of seed germinative process. Fungal incidence was assessed with aid of a countertop magnifying glass with $4 \mathrm{x}$ magnifications; and their identification until genus level was performed with aid of stereomicroscope.

The accelerated ageing (AA) test was performed on samples of 200 seeds from each of the five lots, which were divided into four subsamples of 50 seeds each. The seeds of each subsample were then evenly distributed on a stainless metal screen fixed to the top edge of a plastic box (Gerbox ${ }^{\circledR}$ type) containing $40 \mathrm{~mL}$ distilled water (relative humidity - $\mathrm{RH}$ about $100 \%$ ); or $40 \mathrm{~mL}$ saturated solution of sodium chloride $(\mathrm{NaCl})$ to maintain relative humidity around $76 \%$ (Jianhua and McDonald, 1997). The boxes were then kept in an incubation chamber (BOD type) set to $42^{\circ} \mathrm{C}$, for $0,24,48,72$ and $96 \mathrm{~h}$; and moisture content, as well as percent seed germination, was determined after each incubation period (Brasil, 2009).

The electrical conductivity (EC) test was carried out with different seed soaking periods (2, 4, 6, 8, 10, 12, 14, 16 and $18 \mathrm{~h}$ ). The interactions between seed number and soaking water volume [25/25, 25/50, 50/50 e 50/75 (seeds/mL water)] were also assessed. The test was performed with four replications of 25 or 50 pure seeds with intact pericarp. For all soaking periods assessed, the seeds of each replicate were weighed on a balance with $0.001 \mathrm{~g}$ precision, placed into different volumes of deionized water, and then kept into a germination chamber, at $25^{\circ} \mathrm{C}$, in the dark. Soaking periods were defined according to methodology described by Kohama et al. (2006), and used by Justo et al. (2007) in studies carried out with Eugenia pyriformis Camb. seeds. Results were expressed as $\mu \mathrm{S} . \mathrm{cm}^{-1} \cdot \mathrm{g}^{-1}$ seeds.

To access the activity of isozymes extracted from the seeds were used two samples of $3.0 \mathrm{~g}$ seeds. The seeds were manually macerated in a mortar, together with the antioxidant polyvinylpyrrolidone (PVP) and liquid nitrogen, and subsequently stored at $-80^{\circ} \mathrm{C}$. The extraction buffer, containing sodium phosphate $0.2 \mathrm{M}(\mathrm{pH} 7.5)$ and dithiothreitol (DTT) $(0.1 \%)$, was used at the rate of $400 \mu 1.100 \mathrm{mg}^{-1}$ macerated seeds. The macerate was then centrifuged at $16,000 \mathrm{x}$ g, at $4{ }^{\circ} \mathrm{C}$, for $25 \mathrm{~min}$; and from the supernatant were removed $50 \mu 1$, which were immediately applied to the polyacrylamide gel $7.5 \%$ (separator gel), with $4.5 \%$ of concentrator gel. Electrophoretic run was carried out at $150 \mathrm{~V}$, for $4 \mathrm{~h}$; and as electrode-gel buffer system it was used a solution of TrisGlycine ( $\mathrm{pH}$ 8.9). Following the protocol described by Alfenas et al. (2006), after the run the gels were stained for the following isozymes: superoxide dismutase (SOD), catalase (CAT), esterase (EST), malate dehydrogenase (MDH) and alcohol dehydrogenase (ADH). The enzyme Isocitrate lyase (ICL) was stained with a solution prepared with: $200 \mathrm{mg}$
DL-isocitric acid; $20 \mathrm{mg}$ Nicotinamide Adenine Dinucleotide Phosphate (NADP); 20 mg 3-(4,5-Dimethylthiazol-2-yl)2,5-Diphenyltetrazolium Bromide (MTT); 2 mg Phenazine Methosulphate (PMS); $20 \mathrm{mg}$ magnesium chloride; $100 \mathrm{~mL}$ Tris $0.2 \mathrm{M}$ ( $\mathrm{pH} 8.0$ ); and $0.1 \mu \mathrm{l}$ phenylhydrazine. Results interpretation was based on presence and intensity of bands of each enzyme in the electrophoresis gels.

All experiments were carried out in a completely randomized experimental design. For the AA test, the treatments were arranged in a factorial 5 x 5 ( 5 seed lots $\times 5$ assessment periods). The different interactions between water volumes x soaking periods were separately assessed. Data were subjected to exploratory analyzes to assess assumptions of normality of residuals, homogeneity of variance of treatments, and additivity of the model, before applying ANOVA; and means were compared by the Scott-Knott test, at 5\% probability. Since data obtained in the electrical conductivity test did not have normal distribution subjected to the non-parametric statistics of analysis of variance by ranks; and means were compared by test of Kruskal-Wallis multiple comparisons (Hollander and Wolfe, 1973). All statistical analyzes were performed with the aid of the statistical programs SISVAR $^{\circledR}$ (Ferreira, 2000) and Action ${ }^{\circledR}$.

\section{Results and Discussion}

The crambe seeds moisture content has ranged from $7.4 \%$ to $8.6 \%$ (Table 1 ). These values are within the optimal range usually used for storing the oilseeds; which, according to Brooker et al. (1992) should be within the range of $6.0 \%$ and $10.0 \%$ moisture. According to Hampton and TeKrony (1995) and Krzyzanowski et al. (1999) when different seed lots are compared, the seed moisture content should be similar for the results of AA and EC tests are similar. Besides, seeds with high moisture content tend to deteriorate faster under the moisture conditions in which the AA test is usually carried out (Marcos-Filho, 2005).

Through percentage of normal emerged seedlings in the FCG and FGC tests individually, as well as by the GSI, the seeds of lot 3 were considered as high quality; the seeds of lots 1 and 5 as intermediate quality; and the seeds of lots 2 and 4 as low quality (Table 1). However, as a whole the germination test demonstrated to be less sensitive on detecting differences in the percentage of normal seedlings emerged, since it has only differentiated the seeds of lot 3 as higher quality in relation to seeds of the other seed lots (Table 1). The percent normal seedlings emerged was higher, both at the initial stand (IS) test as at the final stand (FS) test, only for the seedlings originating from seeds of lot 3 , in relation to the other seed 
lots; besides the seeds of lot 5 have shown the lowest values for these two parameters. The mean values obtained by the ESI for the seeds of lot 5 were also lower than the mean values found to the seeds of the other seed lots (Table 1).

The fungus Cladosporium $\mathrm{sp}$. was the microorganism with the highest incidence in the crambe seeds originating from all five different seed lots, followed by the fungi Fusarium sp., Penicillium sp., and Alternaria sp. (Table 2). The seeds of lot 3 , which had the highest germination percentage (Table 1), were those that have had the lowest incidence of pathogenic fungi, with only $4 \%$ incidence of fungi of genera Cladosporium sp. (2\%) and Fusarium sp. (2\%) (Table 2).

Table 1. Mean values obtained to moisture content (MC), first count of germination (FCG), final germination count (FGC), seed germination speed index (GSI); initial seedling stand (IS) and final seedling stand (FS); and emergence speed index (ESI), from seeds of five lots of crambe.

\begin{tabular}{cccccccr}
\hline \multirow{2}{*}{ Seed lot } & \multicolumn{9}{c}{ Test } \\
\cline { 2 - 8 } & MC (\%) & FCG (\%) & FGC (\%) & GSI & IS (\%) & FS (\%) & ESI \\
\hline 1 & $7.7 \mathrm{~A} *$ & $67 \mathrm{~B}$ & $71 \mathrm{~B}$ & $25.845 \mathrm{~B}$ & $57 \mathrm{~B}$ & $86 \mathrm{~A}$ & $10.652 \mathrm{~A}$ \\
2 & $8.1 \mathrm{~A}$ & $48 \mathrm{C}$ & $68 \mathrm{~B}$ & $20.520 \mathrm{C}$ & $49 \mathrm{~B}$ & $76 \mathrm{~B}$ & $9.340 \mathrm{~A}$ \\
3 & $8.6 \mathrm{~A}$ & $89 \mathrm{~A}$ & $92 \mathrm{~A}$ & $41.450 \mathrm{~A}$ & $74 \mathrm{~A}$ & $97 \mathrm{~A}$ & $11.837 \mathrm{~A}$ \\
4 & $8.0 \mathrm{~A}$ & $49 \mathrm{C}$ & $58 \mathrm{~B}$ & $20.282 \mathrm{C}$ & $55 \mathrm{~B}$ & $74 \mathrm{~B}$ & $9.484 \mathrm{~A}$ \\
5 & $7.4 \mathrm{~A}$ & $64 \mathrm{~B}$ & $67 \mathrm{~B}$ & $25.937 \mathrm{~B}$ & $21 \mathrm{C}$ & $45 \mathrm{C}$ & $5.152 \mathrm{~B}$ \\
\hline $\mathrm{CV}(\%)$ & 1.20 & 12.03 & 15.22 & 6.00 & 23.10 & 11.00 & 7.58 \\
\hline
\end{tabular}

*Means followed by the same letter in the columns do not statistically differ between each other by the $\mathrm{Scott}-\mathrm{Knott}$ test $(\mathrm{P}<0.05)$. CV $=$ coefficient of variation.

Table 2. Percentage of crambe seeds infected by pathogenic fungi obtained by the health test carried out on seeds of five different seed lots.

\begin{tabular}{ccccc}
\hline \multirow{2}{*}{ Seed lot } & \multicolumn{5}{c}{ Incidence $(\%)$} \\
\cline { 2 - 5 } & Cladosporium $\mathrm{sp}$. & Fusarium $\mathrm{sp}$. & Penicillium $\mathrm{sp.}$ & Alternaria sp. \\
\hline 1 & 34 & 4 & 78 & 20 \\
2 & 15 & 1 & 5 & 1 \\
3 & 2 & 2 & absent & absent \\
4 & 39 & 2 & absent & 1 \\
5 & 8 & 2 & 2 & 23 \\
\hline
\end{tabular}

Likewise, in a study performed with crambe seeds originating from different seed lots of this oilseed produced in the state of Mato Grosso, Masseto et al. (2009) have also reported the incidence of Penicillium sp., Phomopsis sp., and Alternaria brassicicola; although without influencing germination potential of the seeds assessed.

However, the incidence of these fungi in crambe seeds is concerning since besides being highly pathogenic these fungi can turn the seeds into potential sources for spreading these microorganisms to other regions where this crop is grown. These fungi may cause severe damage to crambe plants or remain viable on their debris and also cause damages to the plants used in the next crop rotation system carried out within the same area. Within this same context, on a diseases survey carried out on the crambe crop, Moers et al. (2012) have already reported the occurrence of the fungus Fusarium spp. causing seedling damping-off; as well as of the fungus Alternaria brassicae causing foliar lesions on adult plants.
The fungi of genus Alternaria sp. have already been reported by Majchrzak et al. (2002) as the most common fungi in crambe seeds; and their impact on adult plants of this oilseed crop has also already been reported in the states of Paraná (Carneiro et al., 2009 and Moers et al., 2012), Goiás (Macagnan et al., 2010), and Mato Grosso do Sul (Pitol et al., 2010). However, there are still no reports on the occurrence of fungi from the genus Cladosporium spp. in crambe crop fields. However, on coffee plants the fungus Cladosporium cladosporioides (Fresen.) de Vries is an important endophytic fungus for the biological control of insects and pathogenic fungi involved in the coffee beans deterioration process; and is usually associated to high quality coffee cultivars (Pereira et al., 2005). This same fungus can be used to control aphids of the genus Myzus sp. as well as the whitefly [Bemisia tabaci (Genn.)] (Faria and Magalhães, 2001); however, on the tendrils of the yellow passion fruit (Passiflora edulis Sims. f. flavicarpa Deg.) this fungus can cause a disease known as scab (Negreiros et al., 2004). 
Through data presented on Table 3 it may be observed that the mean values obtained for initial seed moisture content have had a statistically significant variation between values obtained for the different lots assessed, as well as between values obtained in the different evaluation periods. Seeds evaluated after the traditional method have had a $326 \%$ increase on moisture content in relation to the alternative method (Table 3); but have also had a higher growth of fungi in all incubation periods assessed. However, when seeds were assessed after the alternative method, results showed no statistically significant differences between the mean values obtained for moisture content; which have remained within the optimal range recommended for the storage of oilseeds (Table 3); in addition to a lower incidence of pathogenic fungi. According to Krzyzanowski et al. (1999) these differences can be explained by the ability of seeds on balancing their moisture content with the environmental relative humidity, even when these relative humidity levels are higher. On studies performed with seeds of other species of the genus Brassica spp. Costa et al. (2008) and Tunes et al. (2012) have also obtained similar results.

Results of germination test of crambe seeds after being subjected to AA test are shown on Table 4. Through mean percentage of normal seedlings emerged, presented on that table, it is verifiable that, in a general way, only the seeds of lot 3 subjected to accelerated aging test, for $72 \mathrm{~h}$ by the traditional method have had higher germination percent in relation to control treatment, as well as in relation to all other lots assessed. These results coincide with those obtained in the germination test (FCG and FGC), by the GSI, and by the initial stand (IS) and final stand (FS) of the seedlings (Table 1).

Table 3. Mean percentage values obtained to moisture content of crambe seeds from five different lots and subjected to accelerated aging test carried out by the standard method with distilled water; and by the alternative method with saturated $\mathrm{NaCl}$ solution, during different incubation periods.

\begin{tabular}{|c|c|c|c|c|c|c|c|c|c|c|}
\hline \multirow{3}{*}{ Seed lot } & \multicolumn{10}{|c|}{ Method/ Incubation period (hours) } \\
\hline & \multicolumn{5}{|c|}{ Distilled water (100\% RH) } & \multicolumn{5}{|c|}{$\mathrm{NaCl}$ saturated solution $(76 \% \mathrm{RH})$} \\
\hline & $\begin{array}{c}\text { Initial } \\
\text { moisture }\end{array}$ & 24 & 48 & 72 & 96 & $\begin{array}{c}\text { Initial } \\
\text { moisture }\end{array}$ & 24 & 48 & 72 & 96 \\
\hline 1 & $6.7 \mathrm{Ac}^{*}$ & $23.0 \mathrm{Ab}$ & $22.2 \mathrm{Ab}$ & $20.2 \mathrm{Ab}$ & $27.1 \mathrm{Aa}$ & $6.7 \mathrm{Aa}$ & $6.7 \mathrm{Aa}$ & $6.4 \mathrm{Aa}$ & $6.8 \mathrm{Aa}$ & $7.2 \mathrm{Aa}$ \\
\hline 2 & $7.4 \mathrm{Ac}$ & $21.8 \mathrm{Ab}$ & $23.1 \mathrm{Ab}$ & $20.2 \mathrm{Ab}$ & $28.4 \mathrm{Aa}$ & 7.4 Aa & 5.6 Aa & $7.7 \mathrm{Aa}$ & $6.8 \mathrm{Aa}$ & 7.8 Aa \\
\hline 3 & $6.2 \mathrm{Ad}$ & $14.7 \mathrm{Bc}$ & $18.3 \mathrm{Bb}$ & $13.0 \mathrm{Bc}$ & $26.4 \mathrm{Aa}$ & $6.2 \mathrm{Aa}$ & 5.1 Aa & 6.6 Aa & $6.0 \mathrm{Aa}$ & $6.0 \mathrm{Aa}$ \\
\hline 4 & 7.2 Ad & 17.8 Ac & $24.6 \mathrm{Ab}$ & $20.8 \mathrm{Ac}$ & $27.8 \mathrm{Aa}$ & 7.2 Aa & $6.3 \mathrm{Aa}$ & $5.8 \mathrm{Aa}$ & $6.3 \mathrm{Aa}$ & $7.4 \mathrm{Aa}$ \\
\hline 5 & $6.9 \mathrm{Ad}$ & $10.6 \mathrm{Bc}$ & $18.0 \mathrm{Bb}$ & $17.5 \mathrm{Bb}$ & $27.2 \mathrm{Aa}$ & $6.9 \mathrm{Aa}$ & $5.3 \mathrm{Aa}$ & $5.8 \mathrm{Aa}$ & 7.3 Aa & 7.1 Aa \\
\hline $\mathrm{CV}(\%)$ & \multicolumn{5}{|c|}{11.9} & \multicolumn{5}{|c|}{16.9} \\
\hline
\end{tabular}

*Means followed by the same uppercase letter in the column and lowercase case letter on the line do not statistically differ between each other by the ScottKnott test $(\mathrm{P}<0.05)$.

Table 4. Mean of the normal seedlings (\%) in the germination test of crambe seeds from five lots, after different periods of accelerated aging by the standard method, and by the alternative method with $\mathrm{NaCl}$ saturated solution.

\begin{tabular}{|c|c|c|c|c|c|c|c|c|c|c|}
\hline \multirow{3}{*}{ Seed lot } & \multicolumn{10}{|c|}{ Method/ Incubation period (hours) } \\
\hline & \multicolumn{5}{|c|}{ Standard method (100\% UR) } & \multicolumn{5}{|c|}{ Alternative method ( $76 \%$ UR) } \\
\hline & Control & 24 & 48 & 72 & 96 & Control & 24 & 48 & 72 & 96 \\
\hline 1 & $72 \mathrm{Bb}^{*}$ & $95 \mathrm{Aa}$ & $83 \mathrm{Ab}$ & $81 \mathrm{Bb}$ & $85 \mathrm{Ab}$ & $72 \mathrm{Bb}$ & $84 \mathrm{Aa}$ & $85 \mathrm{Aa}$ & $86 \mathrm{Aa}$ & $88 \mathrm{Aa}$ \\
\hline 2 & $75 \mathrm{Bb}$ & $69 \mathrm{Bb}$ & $89 \mathrm{Aa}$ & $81 \mathrm{Ba}$ & $68 \mathrm{Bb}$ & $75 \mathrm{Ba}$ & $91 \mathrm{Aa}$ & $85 \mathrm{Aa}$ & $80 \mathrm{Aa}$ & $84 \mathrm{Aa}$ \\
\hline 3 & $87 \mathrm{Aa}$ & $95 \mathrm{Aa}$ & $92 \mathrm{Aa}$ & $91 \mathrm{Aa}$ & $89 \mathrm{Aa}$ & $87 \mathrm{Aa}$ & $93 \mathrm{Aa}$ & $85 \mathrm{Aa}$ & $88 \mathrm{Aa}$ & $85 \mathrm{Aa}$ \\
\hline 4 & $77 \mathrm{Ba}$ & $80 \mathrm{Ba}$ & $63 \mathrm{Bb}$ & $55 \mathrm{Cb}$ & $20 \mathrm{Cc}$ & $77 \mathrm{Ba}$ & $87 \mathrm{Aa}$ & $76 \mathrm{Aa}$ & $59 \mathrm{Bb}$ & $62 \mathrm{Bb}$ \\
\hline 5 & $68 \mathrm{Ba}$ & $84 \mathrm{Ba}$ & $79 \mathrm{Aa}$ & $75 \mathrm{Ba}$ & $76 \mathrm{Ba}$ & $68 \mathrm{Ba}$ & $73 \mathrm{Ba}$ & $75 \mathrm{Aa}$ & $56 \mathrm{Bb}$ & $55 \mathrm{Bb}$ \\
\hline $\mathrm{CV}(\%)$ & & & 10.32 & & & & & 9.87 & & \\
\hline
\end{tabular}

* Means followed by the same lowercase letter on the line and uppercase in the columns do not statistically differ from each other by the Scott-Knott test and $\mathrm{F}$ test $(\mathrm{P}<0.05) ; \mathrm{CV}=$ coefficient of variation.

Moreover, in all incubation periods assessed the crambe seeds of lot 3 , both those evaluated by the standard method as those evaluated by the alternative method have had their germination percentage increased as compared to control treatment (Table 4). Likewise, in a study conducted with seeds of broccoli (Brassica oleracea L. var. italica Plenck), Mello et 
al. (1999) have also observed that seeds with higher vigor, even when incubated for different periods, have led to an increased percentage of normal seedlings emerged in all incubation periods assessed. However, Ward and Powell (1983) in a study with onion (Allium cepa L.) seeds have observed that when seeds have reached between $20 \%$ and $25 \%$ moisture content under high temperatures they have had their deterioration delayed and increase on germination rate.

When assessed by the AA test standard method $(100 \%$ $\mathrm{RH})$, the seeds from the lot 4 have shown a germination decline (from $77 \%$ to $55 \%$ ) at the $72 \mathrm{~h}$ incubation period, in relation to the control treatment, reaching only $20 \%$ germination at the $96 \mathrm{~h}$ incubation period; thus allowing to rank them as the least vigorous seeds among the five lots studied. However, when seeds of same lot were evaluated by the alternative method $(76 \% \mathrm{RH})$, they have shown no statistically significant differences between the mean values obtained for seed germination in all incubation periods assessed. Nevertheless, the seeds from lot 3, which already had been sorted as higher vigor by the germination test (FCG and FGC) and seedling emergence (IS and FS) (Table 1) had no statistically significant change on germination percentage when evaluated by the AA test using the two different incubation methods (Table 4). Hence, by the AA test, the seeds of lots 1 and 3 were ranked as high vigor, the seeds of lots 2 and 5, as intermediary vigor, and the seeds of lot 4 as the least vigorous seeds. These results confirm what has already been emphasized by Santos and Rossetto (2013), who recommend the inclusion of $\mathrm{NaCL}$ saturated solution and temperature of $45{ }^{\circ} \mathrm{C}$ in the methodology of the AA test on assessing vigor of crambe seeds. However, further studies on the ideal temperature for the AA test in seeds of this oilseed are still needed.

Through mean results obtained by the EC test (Tables 5 and 6) it is verifiable that there were statistically significant differences between the mean values obtained for the physiological quality of the seeds originating from the different lots assessed, but these differences were not as marked as those observed in the remaining tests. However, in relation to the different soaking periods used, the seeds of lots 3 and 4 were classified as those of higher vigor, and the seeds of lots 1,2 , and 4 as those of lower vigor (Table 5). Concerning the correlation between seed number/volume deionized water for seed imbibition (Table 6), the ratio 25/25 has allowed ranking the seeds of the different lots into four different vigor levels; i.e., the seeds from lot 3 were sorted as the ones with the highest vigor; the seeds from lot 5 as of intermediate vigor, the seeds of lot 4 as of low vigor, and the seed from the lots 1 and 2 as having unacceptable vigor level for sowing. The ratios of $25 / 50,50 / 50$, and 50/75 were less efficient for ranking the lots by the vigor of their seeds, distinguishing only the lots 3 and 5 from the other lots assessed (Table 6).

Table 5. Mean results of the electrical conductivity $\left(\mu \mathrm{S} . \mathrm{cm}^{-1} \cdot \mathrm{g}^{-1}\right)$ of crambe seeds from five lots after different seed imbibition periods.

\begin{tabular}{cccccc}
\hline \multirow{2}{*}{ Imbibition period $(\mathrm{h})$} & \multicolumn{3}{c}{ Seed lot } \\
\cline { 2 - 5 } & 1 & 2 & 3 & 4 & 5 \\
\hline 2 & $665 \mathrm{bA} *$ & $717 \mathrm{bA}$ & $58 \mathrm{aA}$ & $446 \mathrm{bA}$ & $157 \mathrm{aA}$ \\
4 & $701 \mathrm{bA}$ & $747 \mathrm{bA}$ & $77 \mathrm{aA}$ & $470 \mathrm{bA}$ & $181 \mathrm{aA}$ \\
6 & $702 \mathrm{bA}$ & $753 \mathrm{bA}$ & $89 \mathrm{aA}$ & $479 \mathrm{bA}$ & $199 \mathrm{aA}$ \\
8 & $724 \mathrm{bA}$ & $772 \mathrm{bA}$ & $101 \mathrm{aA}$ & $488 \mathrm{bA}$ & $225 \mathrm{aA}$ \\
10 & $731 \mathrm{bA}$ & $792 \mathrm{bA}$ & $114 \mathrm{aA}$ & $504 \mathrm{bA}$ & $239 \mathrm{aA}$ \\
12 & $742 \mathrm{bA}$ & $797 \mathrm{bA}$ & $124 \mathrm{aA}$ & $511 \mathrm{bA}$ & $258 \mathrm{aA}$ \\
14 & $758 \mathrm{bA}$ & $819 \mathrm{bA}$ & $130 \mathrm{aA}$ & $522 \mathrm{bA}$ & $266 \mathrm{aA}$ \\
16 & $785 \mathrm{bA}$ & $851 \mathrm{bA}$ & $138 \mathrm{aA}$ & $522 \mathrm{abA}$ & $271 \mathrm{aA}$ \\
18 & $807 \mathrm{bA}$ & $877 \mathrm{bA}$ & $140 \mathrm{aA}$ & $533 \mathrm{abA}$ & $276 \mathrm{aA}$ \\
\hline
\end{tabular}

*Means followed by the same lowercase letter on the lines and uppercase letter in the columns do not statistically differ between each other by the KruskalWallis and multiple comparisons tests $(\mathrm{P}<0.05)$.

Vanzolini and Nakagawa (2005), in a study carried out on electrical conductivity of peanut (Arachis hypogaea L.) seeds, had already emphasized that, by demanding greater amount of nutrients (sugars, amino acids, fatty acids, etc.) for the restoration of their cell membranes and reactivation of their metabolism, the less vigorous seeds release higher amounts of enzymes and inorganic ions by leaching during the soaking process. Thus, when evaluated by the EC test, the seeds of lot 3 , for presenting lower values for electrical conductivity (Table 5), as well as for seed/water ratio (Table 6), have been considered as those of highest physiological quality among all lots herein studied. However, differently from results obtained in the other vigor tests (Tables 1 and 4) starting from the ratio 25 seeds $/ 50 \mathrm{~mL}$ water mean values obtained in this test for seeds of lots 3 and 5 were statistically similar (Table 6).

Seeds of lots 1 and 2 were ranked as low vigor by the 
EC test probably because they have been harvested in the 2011 crop season, or for containing mixtures of immature seeds, or yet with latent mechanical damage that could have caused reduction on their vigor during storage. Furthermore, the high values of electrical conductivity of whole seeds, as those used in this study, may be correlated to characteristics of the pericarp, which are structures lignified and carriers of ions that may cause increases on electrical conductivity, or the accumulation of other substances that can cause differences in the permeability of the cell membranes, may have led to misinterpretation of results obtained in this study. Within this context, on studies carried out on electrical conductivity of leachates of sunflower (Helianthus annuus L.) seeds, Albuquerque et al. (2001) have also verified that the pericarp of the seeds evaluated contained substances that may influence seed vigor.

Table 6. Mean results of the electrical conductivity $\left(\mu \mathrm{S} . \mathrm{cm}^{-1} \cdot \mathrm{g}^{-1}\right)$ of crambe seeds from five lots, and assessed in function of the number of seeds/ volume of the soaking water in the ratios of $25 / 25,25 / 50,50 / 50$, and 50/75.

\begin{tabular}{ccccr}
\hline \multirow{2}{*}{ Seed lot } & \multicolumn{4}{c}{ Seed number/volume deionized water $(\mathrm{mL})$} \\
\cline { 2 - 5 } & $25 / 25$ & $25 / 50$ & $50 / 50$ & \multicolumn{1}{c}{$50 / 75$} \\
\hline 1 & $1223 \mathrm{CDb}^{*}$ & $647 \mathrm{Cab}$ & $629 \mathrm{BCab}$ & $442 \mathrm{Ba}$ \\
2 & $1358 \mathrm{Db}$ & $692 \mathrm{Cab}$ & $658 \mathrm{Cab}$ & $460 \mathrm{Ba}$ \\
3 & $178 \mathrm{Ab}$ & $97 \mathrm{Aab}$ & $93 \mathrm{Aa}$ & $64 \mathrm{Ab}$ \\
4 & $859 \mathrm{Cb}$ & $413 \mathrm{Ba}$ & $415 \mathrm{Ba}$ & $302 \mathrm{Ba}$ \\
5 & $410 \mathrm{Ba}$ & $211 \mathrm{Aa}$ & $180 \mathrm{Aa}$ & $121 \mathrm{Aa}$ \\
\hline
\end{tabular}

*Means followed by the same lowercase letter on the lines and uppercase letter in the columns do not statistically differ between each other by the Kruskal-Wallis, and multiple comparisons tests $(\mathrm{P}<0.05)$.

Because of incoherencies on results obtained in the EC test, it was not possible sorting the different lots by physiological quality of their seeds. However, such test was efficient for assessing vigor of seeds of other major oilseed crops such as castor bean (Ricinus communis L.) (Mendes et al., 2010) and sunflower (Albuquerque et al., 2001). Therefore, for the EC test is used to efficiently evaluate vigor of crambe seeds, more detailed studies on the substances present in the seed pericarp and that are linked to their release to the soaking water are still required, to then determine a specific methodology for this test to assess vigor of this species seeds.

As for electrophoretic profile of crambe seed extracts, bands stained for the enzymes SOD and CAT on the polyacrylamide gels show that the activity of this two isozymes, which are related to the protection system against reactive forms of oxygen, were similar in the seeds of all the five lots assessed; except in the seeds of lots 1 , where the activity of enzymes
SOD and CAT in the seeds was low (Figure 1). Therefore, the low physiological quality of the seeds from the lot 1 may be related to the low activity of the CAT enzyme, since such enzyme is responsible for the removal of toxic products produced by the SOD enzyme. These results are similar to those found by Ataíde et al. (2012), who in studies conducted to evaluate physiological and biochemical changes that occur in seeds of Pterogyne nitens Tul. during accelerated aging, have also verified that the low activity of the CAT enzyme may cause reduction on seed germination capacity.

Furthermore, the low activity of isozymes SOD and CAT in the seeds of lot 1 may also be explained as a low need of these two enzymes by the seeds from such lot; once these seeds have presented vigor similar to those sorted as higher vigor, or intermediary vigor, when assessed by the seedling emergence test (IS and FS) (Table 1). Therefore, for crambe seed the activity of these two isozymes should be assessed together.

By the electrophoretic profile of isozymes, it can also be observed that the EST enzyme activity was higher in the seeds of lots 2, 3, and 4 (Figure 1). On this subject, in a study on the changes occurring in the activity of EST enzyme on peanut seed deterioration, Aung and McDonald (1995) have reported that the activity of such enzyme was the main factor responsible for deterioration of the assessed seeds. Therefore, by results herein obtained it can be inferred that the activity of enzyme EST is much higher in seeds of oilseed crops, as those of crambe, than in seeds of non-oilseed crops; and thus requiring more care to prevent their deterioration during storage.

The bands stained for the $\mathrm{MDH}$ enzyme in the polyacrylamide gel were more evident and similar in the seeds of all the lots assessed (Figure 1). According to Taiz and Zeiger (2004), the MDH is an enzyme of the Krebs cycle that, by catalyzing the conversion of malate to oxaloacetate produces the coenzyme 1 [Nicotinamideadenine-dinucleotide (NADH)] which will be used for the generation of cellular energy, besides participating in the respiratory process of cells and, therefore, its presence in the seeds should always be studied on assessing the physiological seed quality.

In its turn, the bands stained for enzyme $\mathrm{ADH}$ were similar in the seeds of lots 2,3 , and 4 , less evident in the seeds of lot 1, and absent in the seeds of lot 5 (Figure 1). According to Faria et al. (2003) and Taiz and Zeiger (2004), the $\mathrm{ADH}$ is an enzyme activated by anaerobic respiration and participates in the recycling of the coenzyme Nicotinamide Adenine Nucleotide (NAD), which in its oxidized form $(\mathrm{NAD}+$ ) acts in the respiratory activity of seeds. However, these authors emphasize that this enzyme reacts with the ethanol released during deterioration 
process and produces acetaldehyde, which is toxic to seeds. In previous studies developed on the activity of such enzyme in the deterioration of coffee seeds, Brandão Junior et al. (2002) had already reported that the dry seeds had shown a linear vigor decline during storage. Subsequently, in a study conducted with pepper (Capsicum spp.) seeds Vidigal et al. (2009) have observed that the electrophoretic profiles obtained for seeds originating from ripe fruits

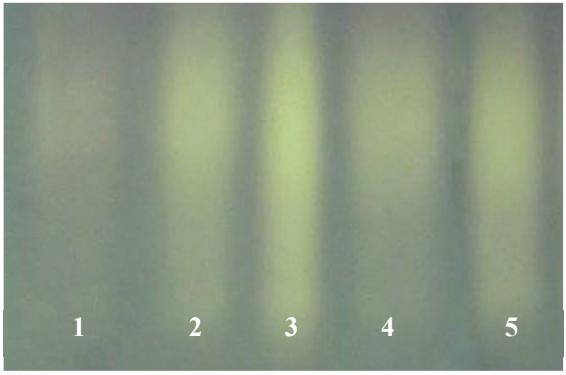

SOD

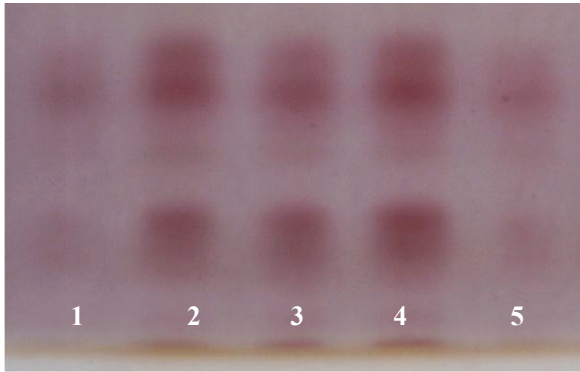

EST

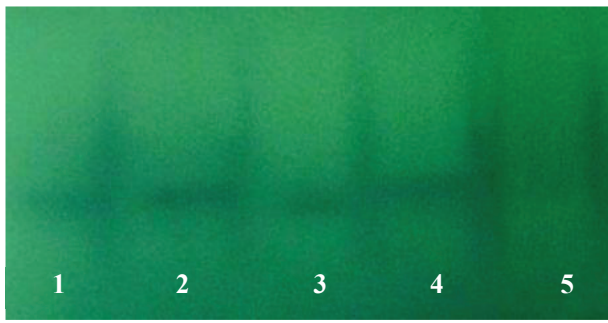

$\mathrm{ADH}$ showed that any change in the number or intensity of bands stained for MDH enzyme were correlated to seed vigor; and that those seeds require an energy supply more intense to their respiratory activity. Therefore, the electrophoretic profiles obtained in this study for enzyme ADH show that absence of this enzyme in the seeds help to explain the low physiological quality of seeds of lot 5 .

Figure 1. Electrophoretic profile of enzymes superoxide

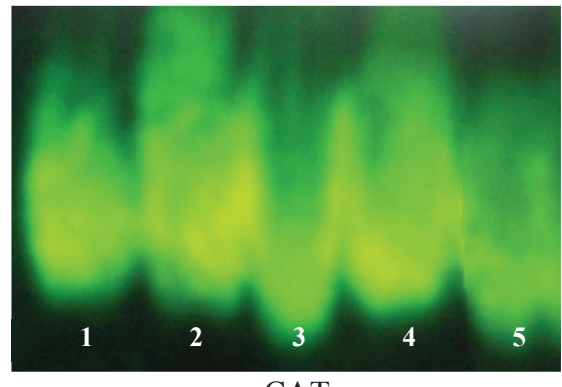

CAT

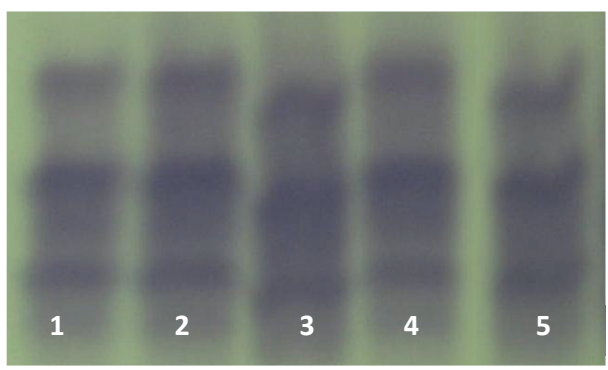

$\mathrm{MDH}$

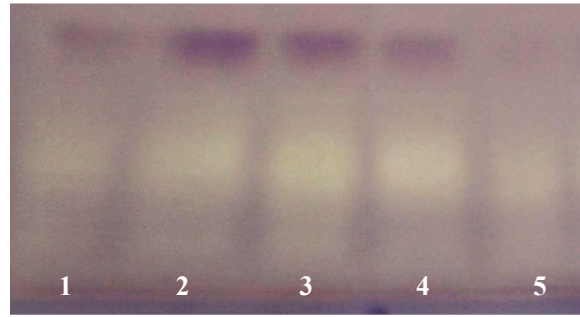

ICL

dismutase (SOD), catalase (CAT), esterase (EST), malate dehydrogenase (MDH), alcohol dehydrogenase (ADH), and isocitrate lyase (ICL) extracted from five seed lots of crambe.

Bands stained for enzyme ICL were clearly evident in extracts of seeds from lot 3 , less evident in extracts of seeds of lots 2 and 4, and unclear in extracts of seeds from lots 1 and 5 (Figure 1). According to Ventura et al. (2012), the ICL enzyme belongs to the glyoxylate cycle and is an alternative used by some plant species as carbon source for the synthesis of glucose; thus providing the required energy for seed germination and seedling development. The authors also emphasize that ICL enzyme is important for elucidating the molecular pathways associated to seed vigor as well as for the understanding the kinetics of seed aging process. Therefore, the low activity of this enzyme may have been the contributing factor for the high levels of electrical conductivity of the seeds from the lot 1 (Table 6), and of the low percentage of the initial (IS) and final (FS) emergence of the seedlings originating from the lot 5 (Figure 1).

\section{Conclusions}

The conventional accelerated aging test carried out at $42{ }^{\circ} \mathrm{C}$, for 96 hours, is efficient to sort different crambe seeds lots by 
the different vigor levels of their seeds.

The conventional electrical conductivity test is not suitable for evaluation of crambe seed vigor.

Low vigor seed lot had high activity of esterase, superoxide dismutase and catalase. There is no activity of isocitrate lyase ang alcohol desidrogenase in the lower vigor seed. There is no change in malate dehydrogenase activity.

\section{Acknowledgements}

To MS Foundation for providing the crambe seeds; to Fundação de Amparo à Pesquisa do Estado de Minas Gerais (FAPEMIG) and Coordenação de Aperfeiçoamento de Pessoal de Nível Superior (CAPES) by the financial support.

\section{References}

ALBUQUERQUE, M.C.F.; MORO, F.V.; FAGIOLI, M.; RIBEIRO, M.C. Teste de condutividade elétrica e de lixiviação de potássio na avaliação da qualidade fisiológica de sementes de girassol. Revista Brasileira de Sementes, v.23, n.1, p.1-8, 2001. http://www.abrates.org.br/revista/artigos/2001/v23n1/artigo01.pdf

ALFENAS, A.C. Eletroforese e marcadores bioquímicos em plantas e microorganismos. 2.ed. Viçosa-MG: UFV, 2006. 627 p.

ATAIDE, G.M.; FLORES, A.V.; BORGES, E.E.L. Alterações fisiológicas e bioquímicas em sementes de Pterogyne nitens Tul. durante o envelhecimento artificial. Pesquisa Agropecuária Tropical, v.42, n.1, 2012. http://www. revistas.ufg.br/index.php/pat/article/view/16497/10439

AUNG, U.T.; McDONALD, M.B. Changes in esterase activity associated with peanut (Arachis hipogaea L.) seed deterioration. Seed Science and Technology, v.23, n.1, p.101-111, 1995. http://agris.fao.org/agris-search/ search/display.do?f=1996/CH/CH96001.xml;CH9600072

ÁVILA, M. R.; BRACINI, A.L.; SCAPIM, C.A.; MARTORELLI, D.T.; ALBRECHT, L.P. Testes de laboratório em sementes de canola e a correlação com a emergência das plântulas em campo. Revista Brasileira de Sementes, v.27, n.1, p.62-76, 2005. http://www.scielo.br/pdf/rbs/v27n1/25182.pdf

BRANDÃO JUNIOR, R.D.S.; VIEIRA, M.G.G.C.; GUIMARÃES, R.M.; HILHORST, H.W.M. Tolerância à dessecação de sementes de cafeeiro (Coffea arabica L.). Revista Brasileira de Sementes, v.24, n.2, p.17-23, 2002. http://www.scielo.br/pdf/rbs/v24n2/v24n2a04.pdf

BRASIL. Ministério da Agricultura, Pecuária e Abastecimento. Manual de análise sanitária de sementes. Ministério da Agricultura, Pecuária e Abastecimento. Secretaria de Defesa Agropecuária. Brasília: MAPA/ACS, 2009. 200 p. http://www.agricultura.gov.br/arq_editor/file/12261_sementes_-web.pdf

BRASIL. Ministério da Agricultura, Pecuária e Abastecimento. Regras para análise de sementes. Ministério da Agricultura, Pecuária e Abastecimento. Secretaria de Defesa Agropecuária. Brasília: MAPA/ACS, 2009. 365p. http:// www.agricultura.gov.br/arq_editor/file/laborat $\%$ c3\%b3rio/sementes/regras $\% 20$ para $\% 20$ analise $\% 20 \mathrm{de} \% 20$ sementes.pdf.

BROOKER, D.B.; BAKKER-ARKEMA, F.W.; HALL, C.W. Theory and simulation of grain drying. In: BROOKER, D.B.; BAKKER-ARKEMA, F.W.; HALL, C.W. Drying and storage of grains and oilseeds. New York: Van Nostrand Reinholdy, 1992. p.205-240.
CARNEIRO, S.M.T.G.; ROMANO, E.; MARIANOWSKI, T.; OLIVEIRA, J. P.; GARBIN, T. H. S.; ARAÚJO, P.M. Ocorrência de Alternaria brassicicola em crambe (Crambe abyssinica) no estado do Paraná. Summa Phytopathology, v.35, n.2, p.154, 2009. http://www.scielo.br/pdf/sp/v35n2/v35n2a16.pdf

COSTA, C.J.; TRZECIAK, M.B.; VILLELA, F.A. Potencial fisiológico de sementes de brássicas com ênfase no teste de envelhecimento acelerado Horticultura Brasileira, v.26, n.2, p.144-148, 2008. http://www.scielo.br/ $\mathrm{pdf} / \mathrm{hb} / \mathrm{v} 26 \mathrm{n} 2 / 03 . \mathrm{pdf}$

FARIA M.R.; MAGALHÃES, B.P. O uso de fungos entomopatogênicos no Brasil. Biotecnologia Ciência \& Desenvolvimento, n.22, p.18-44, 2001. http://www.biotecnologia.com.br/revista/bio22/fungos.pdf

FARIA, M.A.V.R.; PINHO, R. G.; PINHO, E.V.R.; GUIMARAES, R.M Marcadores moleculares da qualidade fisiológica de sementes. Lavras-MG: UFLA/FAEPE, 2003.51p.

FERREIRA, D.F. SISVAR- Sistema de análise de variância para dados balanceados: programa de análises estatísticas e planejamento de experimentos, versão 4.1. Lavras-MG: UFLA, 2000.

HAMPTON, J.G.; TEKRONY, D.M. Handbook of vigour test methods. 3.ed. Zurich: International Seed Testing Association, $1995.117 \mathrm{p}$.

HOLLANDER, M.R.; WOLFE, D.A. Nonparametric statistical methods. New York: John Willey e Sons, 1973. 503p.

JIANHUA, Z; McDONALD, M. B. The saturated salt accelerated aging test for small-seeded crops. Seed Science and Technolology, v.25, n.1, p.123-131, 1997. http://cat.inist.fr/?aModele=afficheNandcpsidt=2682143.

JUSTO, C .F.; ALVARENGA, A. A.; NERY, F.C.; DELU FILHO, N Composição química, curva de embebição e efeito da temperatura sobre a germinação de sementes de Eugenia pyriformis Camb. (Myrtaceae). Revista Brasileira de Biociências, v.5, n.2, p.510-512, 2007. http://www.ufrgs.br/ seerbio/ojs/index. php/rbb/article/view/457/402

KIKUTI, A.L.P; MARCOS-FILHO, J. Physiological potential of cauliflower seeds. Scientia Agricola, v.65, n. 4, p.374-380, 2008. http://www.scielo.br/ $\mathrm{pdf} / \mathrm{sa} / \mathrm{v} 65 \mathrm{n} 4 / 08$.pdf

KOHAMA, S.; MALUF, A.M.; BILIA, D.A.C.; BARBEDO, C.J. Secagem e armazenamento de sementes de Eugenia brasiliensis Lam. (grumixameira). Revista Brasileira de Sementes, v.28, n.1, p. 72-78. 2006.

KRZYZANOWSKI, F.; VIEIRA, R.D.; FRANCA-NETO, J. B. Vigor de sementes: conceitos e testes. Londrina: ABRATES, 1999. 218p.

LAZZERI, L.; LAPENTA, E.; SANTANGELO, E.; MALAGUTI, L.; VENTRELLA, D.; PINHEIRO, M. Crambe abyssinica Hochst ex R.E. Fries: agronomic performance and oil quality in three locations in Italy. Agricoltura Mediterranea, v.125, p.251-266, 1995.

MACAGNAN, D.; CHAVES, Z.M.; CAFÉ-FILHO,A.C. First report of Alternaria brassicicola on Crambe abyssinica in Goiás state, Brazil. Summa Phytopathologica, v.36, n.3, p.260, 2010. http://www.scielo.br/pdf/sp/v36n3/v36n3a16.pdf

MAGUIRE, J.D. Speed of germination-aid in selection and evaluation for seedling emergence and vigour. Crop Science, v.2, n. 1, p.176-177, 1962.

MAJCHRZAK, B.; KUROWSKI, T.P.; TOMAZ, P.; KARPINSKA, Z. The health condition of spring oilseed crops in relation to the fungi colonizing their seeds. Acta Agrobotanica, v.55, n.1, p. 199- 210, 2002. http://www.ibpan.krakow.pl/pubs/articles?pub $=8$ andannual $=2002$ andart $=418$

MARCOS-FILHO, J. Fisiologia de sementes de plantas cultivadas. Piracicaba: FEALQ, 2005. 495p. 
MARTINS, C.C.; MARTINELLI-SENEME, A.; CASTRO, M.M.; NAKAGAWA J.; CAVARIANI, C. Comparação entre métodos para a avaliação do vigor de lotes de sementes de couve-brócolos (Brassica oleracea L. var. italica Plenk). Revista Brasileira de Sementes, v.24, p. 96-101, 2002. http://www.pscielo.br/pdf/rbs/v24n2/v24n2a16.pdf

MASSETO, T.E.; QUADROS, J.B.; MOREIRA, F.H.; RIBEIRO D.M.; BENITES JUNIOR, I.; RESENDE, R.K.S. Qualidade fisiológica e sanitária de sementes de crambe produzidas no estado do Mato Grosso do Sul. Revista Brasileira de Oleaginosas e Fibrosas, v.13, n.3, p.107-113, 2009. http:// www.cnpa.embrapa.br/rbof/fasciculos.php

MELLO, S.C.; SPINOLA, M.C.M.; MINAMI, K. Métodos de avaliação da qualidade fisiológica de sementes de brócolos. Scientia Agricola, v.56, n.4, supl., p.1151-1155, 1999. http://www.scielo.br/pdf/sa/v56n4s0/a17v564s.pdf

MENDES, R.C.; DIAS, D.C .F.S.; PEREIRA, M.D.; DIAS, L.A.S. Testes de vigor para avaliação do potencial fisiológico de sementes de mamona (Ricinus communis L.). Ciência e Agrotecnologia, v.34, n.1, p.114-120, 2010. http://www.scielo.br/pdf/cagro/v34n1/15.pdf

MILANI, M.; MENEZES, N.L.; LOPES, S.J. Teste de condutividade elétrica para avaliação do potencial fisiológico de sementes de canola. Revista Ceres, v.59, n.3, p.374-379, 2012. http://www.scielo.br/pdf/rceres/v59n3/a12v59n3.pdf

MOERS, E.M.; KUHN, O.J.; GONCALVES JR., A.C.; FRANZENER, G.; STANGARLIN, J.R. Levantamento de doenças na cultura do crambe (Crambe abyssinica Hochst) na região oeste do Paraná. Scientia Agraria Paranaenis, v.11, n.1, p.35-48, 2012. http://cac-php.unioeste.br/pos/media/ File/energia agricultura/Levantamento de doencas na cultura.pdf

NEGREIROS, J. R. S.; BRUCKNER, C.H.; CRUZ, C.D.; SIQUEIRA, D.L.; PIMENTEL, L.D. Seleção de progênies de maracujazeiro-amarelo vigorosas e resistentes à verrugose (Cladosporium cladosporioides). Revista Brasileira de Fruticultura, v.26, n.2, p. 272-275, 2004. http://www.scielo.br/pdf/rbf/ v26n2/21823.pdf

PEREIRA, R.T.G.; PFENNING, L.H.; CASTRO, H.A. Caracterização e dinâmica de colonização de Cladosporium cladosporioides (Fresen.) de Vries em frutos do cafeeiro (Coffea arabica L.). Ciência e Agrotecnologia, v.29, n.6, p. 1112-1116, 2005. http://www.scielo.br/scielo.php?script=sci arttextandpid $=$ S141370542005000600002andlng $=$ enandnrm $=$ iso $>$.
PITOL, C.; BROCH, D.L.; ROSCOE, R. Tecnologia e produção: crambe 2010. Maracaju: Fundação MS, 2010. 60p.

SANTOS, L.A.S.; ROSSETTO, C.A.V. Testes de vigor em sementes de Crambe abyssinica. Ciência Rural, v. 43, n.2, p. 233-238, 2013. http:// www.scielo.br/pdf/cr/v43n2/a5913cr6527.pdf

SOUZA, L.A.; CARVALHO, M.L.M.; KATAOKA, V.Y.; OLIVEIRA, J.A Teste de condutividade elétrica para avaliação da qualidade fisiológica de sementes de mamona. Revista Brasileira de Sementes, v.31, n.1, p.60-67, 2009. http://www.scielo.br/pdf/rbs/v31n1/a07v31n1.pdf

TAIZ, L.; ZEIGER, E. Plant physiology. Califórnia: Cummings, 2004. 565p.

TUNES，L.M; TAVARES，L.C.; RUFINO, C.A.; BARROS, A.C.S.A., MUNIZ, N.F.B., DUARTE, V.B. Envelhecimento acelerado em sementes de brócolis (Brassica oleracea L. Var. Italica Plenk). Bioscience Journal, v.28, n.2, p.173-179, 2012. http://www.seer.ufu.br/index.php/biosciencejournal/ article/view/11636/8475

VANZOLINI, S.; NAKAGAWA, J. Teste de condutividade elétrica em sementes de amendoim. Revista Brasileira de Sementes, v.27, n.2, p.151158, 2005. http://www.scielo.br/pdf/rbs/v27n2/a22v27n2.pdf

VENTURA, L.; DONÀ, M.; MACOVEI, A.; CARBONERA, D.; BUTTAFAVA, A.; MONDONI, A.; ROSSI, G.; BALESTRAZZI, A. Understanding the molecular pathways associated with seed vigor. Plant Physiology and Biochemistry, v.60, p.196-206, 2012. http://www. sciencedirect.com/science/article/pii/S0981942812002100

VIDIGAL, D.S.; DIAS, D.C.F.S.; VON PINHO, E.V.R.; DIAS, L.A.S Alterações fisiológicas e enzimáticas durante a maturação de sementes de pimenta (Capsicum annuum L.). Revista Brasileira de Sementes, v.31, n.2, p.129-136, 2009. http://www.scielo.br/pdf/rbs/v31n2/v31n2a15.pdf

WARD, F.H.; POWELL, A.A. Evidence for repair processes in onion seeds during storage at high seed moisture contents. Journal of Experimental Botanic, v.34, n.140, p.277-282, 1983. 